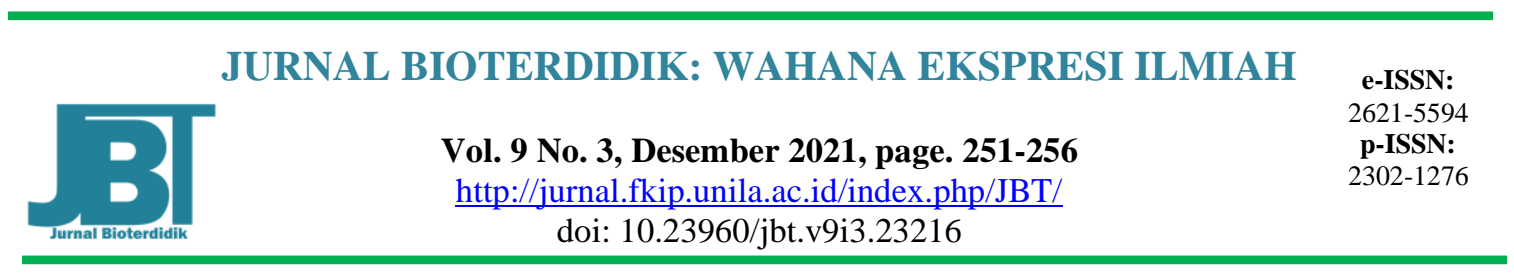

\title{
Extranous Cognitive Load (ECL) Mahasiswa Calon Guru dalam Pelaksanaan Perkuliahan Pendidikan Biologi
}

\author{
Iffa Ichwani Putri*, Nurul Fauziah, Yelifra Sari \\ Pendidikan Biologi, Fakultas Keguruan dan Ilmu Pendidikan, Universitas Islam Riau, Jl. Kaharuddin \\ Nasution Pekanbaru-Riau, Indonesia \\ *e-mail: iffa.ichwani@edu.uir.ac.id
}

\begin{abstract}
Extraneous Cognitive Load (ECL) Prospective Teacher in the Implementation of Biology Education. This study aims to determine the ECL of prospective teacher students during lectures. ECL is obtained from the mental effort of students in attending lectures or teaching and learning processes because it will affect the process of constructing students' cognitive schemas from the information received during the learning process. Learning activities are effective and efficient if the ECL of students is in the low category. Data collection was carried out on biology education students who attended group lectures for pedagogic courses and biological science content in the odd semester 2020/2021. This is a descriptive study which was conducted in MarchSeptember 2021, with the determination of the sample, namely purposive random sampling. ECL was measured using a mental effort questionnaire in each course in the learning process. The data obtained were analyzed in the conversion of low to high scores, then compared between semester levels to provide an overview of student ECL. The results showed that the mental effort of prospective teacher students was in the low category. The ECL of prospective biology education teacher students is low.
\end{abstract}

Keywords: biology education, cognitive load, mental activity

Abstrak: Extraneous Cognitive Load (ECL) Mahasiswa Calon Guru dalam Pelaksanaan Perkuliahan Pendidikan Biologi. Penelitian ini bertujuan untuk mengetahui ECL mahasiswa calon guru selama perkuliahan berlangsung. ECL diperoleh dari usaha mental mahasiswa dalam mengikuti perkuliahan atau proses belajar mengajar karena akan memberikan pengaruh proses konstruksi skema kognitif peserta didik dari informasi yang diterima selama pembelajaran berlangsung. Kegiatan pembelajaran yang efektif dan efisien apabila $E C L$ peserta didik berada pada kategori rendah. Pengambilan data dilaksanakan pada mahasiswa pendidikan biologi yang mengikuti perkuliahan kelompok mata kuliah pedagogik dan konten keilmuan biologi pada semester Ganjil 2020/2021. Penelitian ini adalah deskriptif yang dilaksanakan pada bulan MaretSeptember 2021, dengan penentuan sampel yaitu purposive random sampling. ECL diukur menggunakan angket usaha mental pada setiap mata kuliah dalam proses pembelajaran. Perolehan data dianalisis pada konversi nilai rendah hingga tinggi, selanjutnya dan dibandingkan antar tingkatan semester untuk memberikan gambaran ECL mahasiswa. Hasil penelitian menunjukkan bahwa usaha mental mahasiswa calon guru berada pada kategori rendah. Sehingga dapat diketahui bahwan ECL mahasiswa calon guru pendidikan biologi adalah rendah.

Kata kunci: beban kognitif, Pendidikan Biologi, usaha mental 


\section{PENDAHULUAN}

Proses pembelajaran merupakan bentuk interaksi antara guru dan peserta didik, dimana keberhasilan peserta didik salah satunya ditentukan oleh kemampuan guru dalam mengajar. Bature et al. (2015) berpendapat bahwa productive pedagogies merupkan kemampuan yang dapat digunakan pendidik untuk meningkatkan pelaksanaan pembelajaran efektif di kelas. Selanjutnya Atweh (2014) menambahkan bahwa productive pedagogies dapat meningkatkan kualitas pembelajaran. Hal ini disebabkan oleh peningkatan interaksi dan komunikasi yang efektif antara pendidik dan peserta didik selama kegiatan pembelajaran.

Kegiatan pembelajaran menjadi penentu beban kognitif peserta didik. Beban kognitif (cognitive load) dapat diartikan sebagai beban pada lingkungan kognitif dalam memenuhi tuntutan tugas yang diberikan selama berlangsungnya proses informasi (Sweller et al., 1994). Paas et al. (2004) menyatakan bahwan cognitive load dapat bersumber dari kompleksnya tugas kognitif, sehingga peserta didik sering terbebani karena jumlah informasi yang diterima melebihi kapasitas sistem kognitif. Sistem kognitif yang menerima informasi secara berlebihan, memerlukan usaha yang maksimal dan menimbulkan keterpaksaan kerja dari system kognitif, yang menyebakan pembelajaran berlangsung tidak bermakna.

Beban kognitif yang ideal adalah dengan pengurangan cognitive load bersumber dari lingkungan belajar ECL. ECL dapat mempengaruhi cara belajar yang digunakan peserta didik dalam mengolah penerimaan informasi dalam sistem kognitif (intrinsic cognitive load). Beban kognitif yang optimal mengakibatkan cognitive load mendukung pembelajaran menjadi efektif (Paas et al., 2004; Jong, 2010).

$E C L$ dapat diketahui dari Usaha Mental (UM) peserta didik selama mengikuti kegiatan pembelajaran, atau lingkungan belajar seperti desain pembelajaran dan strategi pembelajaran yang dilakukan. Keefektifan $E C L$ dipengaruhi oleh informasi dan kegiatan pembelajaran yang mempengaruhi proses konstruksi skema kognitif peserta didik. ECL merupakan cognitive load yang disebabkan oleh hal lain di luar pembelajaran dan materi ajar, seperti lingkungan kelas maupun strategi pembelajaran yang digunakan. Pembelajaran yang baik adalah jika $E C L$ yang dimiliki peseta didik berada pada kategori rendah yang diukur dari usaha mental peserta didik dalam mengikuti pembelajaran. Berdasarkan latar belakang tersebut dilaksanakan penelitian mengenai analisis ECL dalam kegiatan pembelajaran pada mahasiswa pendidikan biologi.

\section{METODE}

Desain penelitian yang digunakan adalah deskriptif dan menggunakan triangulasi melalui kegiatan pengumpulan data kualitatif dan kuantitatif, membandingkan hasilnya, dan menggunakan hasil temuan lain untuk melihat kecenderungan hubungan antar variable yang ada (Creswell, 2007). Hasil yang diperoleh akan dianalisi secara deskriptif.

Perolehan data $E C L$ dianalisis melalui perolehan skor usaha mental peserta didik berdasarkan jawaban kuesioner. Instrumen yang digunakan pada penelitian ini angket Usaha Mental Peserta Didik. Pengukuran Usaha Mental (UM) dilakukan selama pelaksanaan perkuliahan. Populasi penelitian adalah seluruh mahasiswa Program Studi Pendidikan Biologi FKIP Universitas Islam Riau. Teknik sampling yang akan digunakan adalah purposive sampling yaitu mahasiswa Semester III, V dan VII pada semester Ganjil 2020/2021 yang mengikuti perkuliahan pedagogic dan keilmuan biologi. ECL digambarkan melalui nilai usaha mental (UM) peserta didik dari jawaban kuesioner yaitu respon mahasiswa terhadap pembelajaran yang disajikan pada perkuliahan pedagogik dan 
keilmuan biologi. ECL dikatakan rendah apabila nilai UM melalui kuesioner tersebut rendah.

\section{HASIL DAN PEMBAHASAN}

Pengukuran ECL dilakukan melalui pengukuran Usaha Mental (UM) mahasiswa calon guru Pendidikan biologi pada perkuliahan. Data UM diperoleh berdasarkan pendapat mahasiswa melalui kuesioner yang dirancang berdasarkan media pembelajaran yang digunakan dosen dan langkah-langkah pembelajaran yang dilakukan dosen dalam pembelajaran. Penjaringan data ini dilakukan dengan melihat tanggapan mahasiswa terhadap pembelajaran yang dilakukan dosen. Pada penelitian ini usaha mental mahasiswa dikategorikan rendah jika merasa mudah dalam memahami penjelasan dosen, dan mengerjakan tugas yang diberikan dosen. Rerata nilai UM dikategorikan tinggi jika pembelajaran yang dilakukan dianggap sulit.

Tabel 1. Rerata Usaha Mental Mahasiswa Calon Guru Pendidikan Biologi

\begin{tabular}{ccc}
\hline Kelas Responden & Rerata $(\boldsymbol{\%})$ & Kategori \\
\hline A & 34,89 & Rendah \\
\hline B & 37,04 & Rendah \\
\hline C & 34,20 & Rendah \\
\hline Rerata & $\mathbf{3 5 , 3 8}$ & Rendah \\
\hline
\end{tabular}

Secara keseluruhan rerata usaha mental mahasiswa terdapat pada Tabel 1. Rerata usaha mental mahasiswa calon guru berada pada kategori rendah $(35,38)$. Perolehan rerata nilai UM yang lebih tinggi menunjukkan bahwa terdapat beberapa usaha yang dilakukan mahasiswa selain dari kemampuan yang dimilikinya dalam mengikuti perkuliahan. Didukung oleh Rahmat et al. (2014) bahwa peningkatan usaha mental kemungkinan terjadi karena prior knowledge yang kurang sehingga melakukan usaha selain menggunakan kemampuan kognitif internal. Berdasarkan hasil perolehan nilai usaha mental mahasiswa pada penelitian ini bahwa rendahnya usaha mental, mencerminkan media pembelajaran yang digunakan dalam menjelaskam materi adalah baik. Hal ini selaras dengan Sweller (2010) bahwa tinggi dan rendahnya usaha mental mencerminkan baik buruknya strategi pembelajaran yang digunakan.

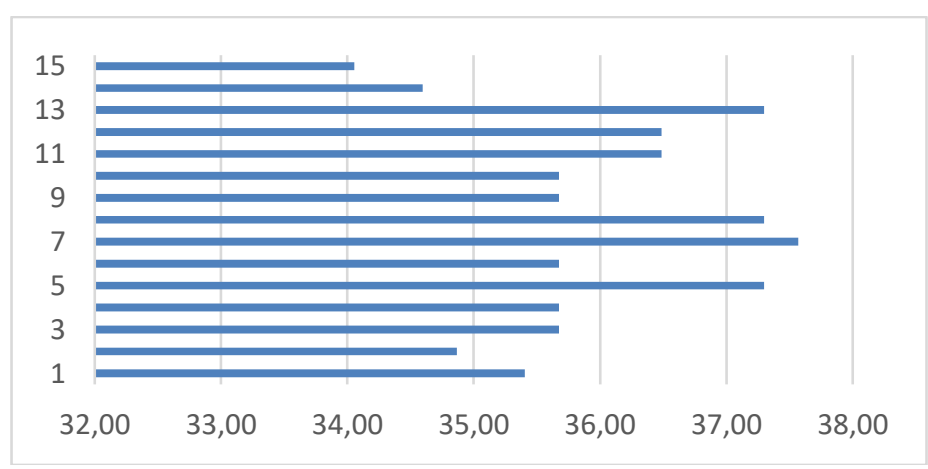

Gambar 1. Rerata UM Dalam Pelaksanaan Perkuliahan

Berdasarkan Gambar 1 diketahui gambaran usaha mental melalui media pembelajaran. Item pernyataan 7 memiliki rerata tertinggi jika dibandingkan dengan yang lainnya. Secara keseluruhan mahasiswa masih memerlukan usaha yang lebih dalam mengerjakan tugas yang diberikan oleh dosen, namun masih berada pada kategori rendah 
$(37,56)$. Selanjutnya mahasiswa calon guru memperoleh usaha mental yang lebih pada item pernyataan 5, 8 dan 13 yaitu pernyataan berkaitan tentang interaksi dan komunikasi, serta kejelasan materi perkuliahan. Berdasarkan angket diketahui bahwa tidak secara maksimal mampu berinteraksi dan diskusi selama perkuliahan berlangsung, sehingga juga membutuhkan usaha mental yang lebih untuk memperoleh kejelasan materi yang dijelaskan. Mayasari (2017) mengungkapkan bahwa penyampaian materi yang terlalu cepat dapat mengakibatkan peserta didik merasa sulit memahami materi. Kesulitan tersebut menjadi penambah beban siswa dalam menerima informasi.

Item pernyataan 3, 4, 6, 9, dan 10 memperoleh rerata nilai yang lebih kurang sama yaitu 35,68. Pernyataan ini berkaitan dengan kemudahan dalam menggunakan media pembelajaran, dan memperoleh informasi yang berkaitan dengan materi perkuliahan melalui media pembelajaran yang digunakan. Selanjutnya pada item 2 dan 15 dengan rerata terendah dibandingkan pernyataan lain yaitu di bawah 35 , menunjukkan bahwa melalui media yang digunakan mahasiswa calon guru antusias dan termotivasi dalam mengikuti perkuliahan.

Komponen ECL diukur berdasarkan usaha mental yang dilakukan peserta didik selama pembelajaran berlangsung terkait strategi pembelajaran yang dilakukan. ECL tidak berhubungan dengan skema kognitif peserta didik tetapi dapat mempengaruhi memori kerja dalam menerima informasi yang diberikan.

Tabel 2. ECL Mahasiswa Calon Guru Melalui Media Pembelajaran

\begin{tabular}{cc}
\hline Penilaian & Nilai /Kategori \\
\hline UM & $\mathbf{3 5 , 3 8}$ \\
\hline ECL & Rendah \\
\hline
\end{tabular}

Berdasarkan Tabel 2, diketahui bahwa nilai usaha mental yang rendah menunjukkan bahwa $E C L$ yang dimilki peserta didik adalah rendah. Menurut Rahmat \& Hindriana (2014) usaha mental merupakan usaha yang dilakukan selain dari menggunakan atau diluar kapasitas sistem kognitif. Pembelajaran yang baik dapat dilihat dari nilai usaha mental yang rendah, yang membuktikan bahwa peserta didik tidak terbebani selama mengikuti pembelajaran.

Brunken et al. (2010) bahwa semakin tinggi kompleksitas tugas belajar, semakin tinggi beban extraneous yang diperoleh oleh peserta didik. Burkes (2007) menyatakan bahwa pembelajaran yang berhubungan dengan cognitive load tidak terlepas dari strategi pembelajaran yang digunakan untuk membantu peserta didik dalam mengolah informasi yang diterima menjadi memori jangka panjang.

\section{SIMPULAN}

Simpulan dari penelitian ini adalah ECL pada mahasiswa calon guru melalui dalam perkuliahan berada pada kategori rendah. Kategori rendah menunjukkan bahwa pembelajaran adalah baik karena dapat menekan beban kognitif asing mahasiswa calon guru pendidikan biologi. 


\section{DAFTAR RUJUKAN}

Arikunto. (2012). Penelitian Tindakan Kelas. Jakarta: Bumi Aksara.

Brunken, R., Seufert, T., \& Paas, F. (2010). Measuring Cognitive Load. Dalam Plass J. L. Moreno R., \& Brünken, R. (eds.). Cognitive Load Theory (hlm. 181 - 202). Cambridge: Cambridge University Press.

Cook, M, P. (2006). Visual Representations In Science Educational: The Influence Of Prior Knowledge And Istructional Design Principles. Science Education. 90 (6): 1073-1091.

Creswell, J, W. (2007). Designing And Conducting Mixed Method Research. California: Sage Publication.

Jong, T, D. (2010). Cognitive Load Theory, Educational Research, And Instructional Design: Some Food For Thought. Educational Research: Springer. 38:105-134.

Kalyuga, S. (2010). Cognitive Load Theory: Recent Theoretical Advances, DalamPlass J. L., Moreno R., \& Brünken, R. (eds.), Cognitive Load Theory (hlm. 48 - 64). Cambridge: Cambridge University Press.

Kalyuga, S. (2011). Informing: A Cognitive Load Perspective. Informing Science: The International Journal of an Emerging Transdiscipline. 14, 33-45.

Mayasari, N. (2017). Beban Kognitif Dalam Pembelajaran Persamaan Differensial Dengan Koefisien Linier Di Ikip Pgri Bojonegoro Tahun Ajaran 2016/2017. Jurnal Silogisme: Kajian Ilmu Matematika dan Pembelajarannya. Vol.2 (1): ISSN: 2527-6182. http://dx.doi.org/10.24269/js.v2il.507.

Minarno, E, B. 2012. Pembelajaran Bioetika Sebagai Pengawal Perkembangan Biologi Modern Dan Penyelamatan Lingkungan Hidup. Pembelajaran Bioetika. 3 (1): 35 40 .

Moreno, R. (2006). When Worked Examples Don't Work: Is Cognitive Load Theory At An impasse? Learning and Instruction, 16(2), 170-181.

OECD. (2014). PISA 2012 Results: What Students Know and Can Do - Student Perforance in Mathematics, Reading and Science (Volume I, Revised Edition, February 2014), PISA, OECD Publishing.

Paas, F., Renkl, A., \& Sweller, J. (2004). Cognitive Load Theory: Instructional Implications Of The Interaction Between Information Structures And Cognitive Architecture. Instructional Science. 32 (1), 1-8.

Paas, F. Renkl, A. \& Sweller, J. (2003). Cognitive Load Theory and Instructional Design: Recent Developments. Educational Psychologist. 38(1), 1-4.

Paas, F., Tuovinen, J.E., Tabbers, H., \& Gerven, P. W. M. V. (2003). Cognitive Load Measurement as a Means to Advance Cognitive Load Theory. Educational Psychologist. 28 (1): 63-71.

Putri, I, I. (2018). Hubungan Komponen Usaha Mental (UM) dan Menerima Mengolah Informasi (MMI) Pada Proses Pembelajaran Biologi. Bioilmi: Jurnal Pendidikan. 4 (2), 53-61.

Putri, I, I., Ferazona, S. (2019). Analisis Usaha Mental (UM) Mahasiswa Sebagai Gambaran Extranous Cognitive Load (ECL) Dalam Kegiatan Perkuliahan Pendidikan Biologi. Perspektif Pendidikan dan Keguruan. Vol X, No. 2, Oktober 2019. ISSN 1411-3570 eISSN 2579-9525.

Rahmat, A., \& Hindriana, F, A. (2014). Beban Kognitif Mahasiswa Dalam Pembelajaran Fungsi Terintegrasi Struktur Tumbuhan. Jurnal Ilmu Pendidikan, hal: 1-18. 
Rahmat, A., Soesilawaty, A., Fachrunnisa, R., Wulandari, S., Suryati, Y., \& Rohaeni, H. (2014). Beban Kogniitif Siswa SMA Pada Pembelajaran Biologi Interdisiplin Berbasis Dimensi Belajar. Seminar Nasional Pendidikan Mathematic and Science University PGRI Semarang, 23 Agustus 2014.

Rahmat, A. (2010). Kajian Terhadap Metode dan Pendekatan Pembelajaran Biologi di SMA: Kesenjangan Dalam Pembelajaran di Kelas. Jurnal Pengajaran MIPA. 15 (1): 25-34.

Sweller, J. (2010). Cognitive Load Theory, Recent Theoritical Advances. Dalam Plass, J, L., Moreno, R., Brunken, R. (eds). Cognitive Load Theory. Cambridge: Cambridge University Press.

Sweller, J. (1994). Cognitive Load Theory, Learning Difficulty, And Instructional Design. Learning and Instruction. 4, 295-312.

Wulf, G., Shea, C.H. (2002). Principles Derived From The Study Of Simple Skills Do Not Generalize To Complex Skills Learning. Psychonomic Bulletin and Review. 9: 185-211. 